\title{
Analysis of subjects with menstrually related migraine vs. Non-menstrually related migraine treated with MAP0004
}

\author{
S Aurora ${ }^{1 *}$, B Lü ${ }^{2}$, E Connors ${ }^{2 *}, X L^{2}$, D Kellerman ${ }^{2}$, S Kori ${ }^{2}$ \\ From The European Headache and Migraine Trust International Congress \\ London, UK. 20-23 September 2012
}

Menstrually related migraine (MRM) is defined as occurring from days -2 to +3 of menstruation in at least 2 out of 3 menstrual cycles, and additionally at other times of the menstrual cycle. MRM is generally longer lasting, more severe, and more difficult to treat compared to non-MRM attacks. MAP0004 is an investigational orally inhaled dihydroergotamine (DHE) for the acute treatment of migraine. In a large Phase 3 study, MAP0004 was effective and well tolerated in treating an acute migraine attack compared to placebo. This post-hoc analysis compares the efficacy of MAP0004 in treating MRM versus non-MRM, including an analysis of recurrence rates using 4 different, previously published recurrence rate definitions. The efficacy of MAP0004, as measured by pain relief at 2 hours, pain free at 2 hours, sustained pain relief at 2-24 and 2-48 hours, and sustained pain free at 2-24 and 2-48 hours values, was not significantly different between subjects with MRM and non-MRM. Furthermore, the MRM recurrence rates after pain relief were not statistically higher than that of non-MRM treated with MAP0004. There were no significant differences in the frequency of adverse events for MRM vs. non-MRM subjects, and no drug-related serious adverse events were reported. In the study, MAP0004 was effective and well-tolerated for both MRM and non-MRM.

\section{Author details \\ 'Swedish Neuroscience Institute, Swedish Headache Center, Seattle, WA, USA. ${ }^{2}$ MAP Pharmaceuticals, USA.}

Published: 21 February 2013

\section{References}

1. Headache Classification Subcommittee of the International Headache Society: The international classification of headache disorders. Cephalalgia 2004, 24(suppl 1).

2. Granella $F$, et al: Characteristics of menstrual and nonmenstrual attacks in women with menstrually related migraine referred to headache centres. Cephalalgia 2004, 24(9):707-716.

3. Sacco S, et al: Migraine in women: the role of hormones and their impact on vascular diseases. J Headache Pain 2012, 13(3):177-89, Epub2012Feb26.

doi:10.1186/1129-2377-14-S1-P143

Cite this article as: Aurora et al: Analysis of subjects with menstrually related migraine vs. Non-menstrually related migraine treated with MAP0004. The Journal of Headache and Pain 2013 14(Suppl 1):P143.
Submit your manuscript to a SpringerOpen ${ }^{\circ}$ journal and benefit from:

- Convenient online submission

- Rigorous peer review

- Immediate publication on acceptance

- Open access: articles freely available online

- High visibility within the field

- Retaining the copyright to your article 